\title{
Active management, value investing and pension fund performance
}

\section{Luis Otero-González, Pablo Durán-Santomil, Rubén Lado-Sestayo and Milagros Vivel-Búa \\ Universidade de Santiago de Compostela, Santiago de Compostela, Spain}

\begin{abstract}
Purpose - This paper analyses whether the active management and the fundamentals of the pension fund allow products that beat their peers to be identified in terms of risk-adjusted performance.

Design/methodology/approach - The sample is composed of all the pension funds active in the period 2000 to 2017 investing in the Eurozone. What this means is that a greater similarity is guaranteed in terms of benchmark, assets available for investment and currency. All the data have been retrieved from the Morningstar Direct database.

Findings - The paper reveals that the degree of concentration and value for money are important determinants of performance. In this sense, the strategies of investing in concentrated portfolios that differ from the benchmark and with undervalued assets in terms of price earnings ratio (PER)-return on assets (ROA) achieve better results.

Originality/value - This is one of the few papers that shows the effect of active management and value investing strategies' on the performance of pension funds.
\end{abstract}

Keywords Individual pension funds, Active management, Value investing, Performance

Paper type Research paper

\section{Introduction}

Pension funds have increased in popularity as a vehicle for long-term saving. Given that profitability determines future income that the beneficiaries receive to a large extent, a relevant question is whether there are selection criteria which can be used to identify pension funds with positive prospects over their rivals. As with mutual funds, the use of brokers or ratings is common. Several studies highlight the lowest profitability of mutual funds recommended by brokers or managed portfolios (Bergstresser et al., 2009; Hackethal et al., 2012; Karabulut, 2013; Armstrong et al., 2017). Regarding the use of ratings, Morningstar data shows that investors use them to invest their savings. During the period 2015-2017, equity pension funds that received a greater flow of funds were those classified as five stars, around 700 million euros, almost equivalent to the one received by those rated four and three (734 million) and much higher than the funds with one and two stars (98 million). However, the existing literature is all related to mutual funds and conclusive results cannot be drawn. Thus, previous research, developed by Howe and Pope (1996), Blake and Morey (2000), Morey (2005) and Chotivetthamrong (2015), concluded that star ratings have little predictive power to identify mutual funds that perform better. However, several studies indicate that investing in assets with better ratings can help to beat its peers

(C) Luis Otero-González, Pablo Durán-Santomil, Rubén Lado-Sestayo and Milagros Vivel-Búa. Published in European Journal of Management and Business Economics. Published by Emerald Publishing Limited. This article is published under the Creative Commons Attribution (CC BY 4.0) licence. Anyone may reproduce, distribute, translate and create derivative works of this article (for both commercial and non-commercial purposes), subject to full attribution to the original publication and authors. The full terms of this licence may be seen at http://creativecommons.org/licences/by/4.0/legalcode
The performance of pension funds

Received 27 August 2020 Revised 22 December 2020 12 February 2021 Accepted 24 February 2021 
EJMBE 30,3 in the long term (Morey and Gottesman, 2006; Müller and Weber, 2014; Meinhardt, 2014 and Otero et al., 2020; Otero and Durán, 2021).

Other relevant criteria related to management types in the field of pension funds have been studied little. Active management is an important source of performance for pension funds (Aglietta et al., 2012). Andonov et al. (2012) decompose pension funds returns it into three active asset management components: asset allocation, market timing and security selection. For each of these components, US pension funds are able to beat their benchmarks, which is different to the results of Coggin et al. (1993) who find selectivity measure is positive and the average timing measure is negative. In the UK, Blake et al. (1999) highlight that is different strategic asset allocation between bonds, equity and cash and not market-timing or security-selection which yields different performance. Cremers and Pareek (2016) and Gonzalez et al. (2020) find that the pension fund's performance increases if a fund is patient (long-term holdings) and has an active investment strategy (hight active share). In the case of mutual funds, several authors have shown that the divergence between the composition of the fund's portfolio and the benchmark can give reasons for a positive effect on performance (Brands et al., 2006; Kacperczyk et al., 2005; Cremers and Petajisto, 2009; Petajisto, 2013 and Cremers, 2017). In addition, value-based management is also considered helpful for finding funds whose future performance beats their competitors'. Within the field of management based on value investing, multiple strategies are included that try to identify quality assets undervalued by the market (Greenblatt, 2006; O'Shaughnessy, 2011; Asness et al., 2019; Paramés, 2016; Blackburn and Cakici, 2017).

Despite there being several studies about the determinants of pension funds' performance, like the gender of the manager (Niessen and Ruenzi, 2007 and Alda, 2016), the experience (Kempf et al., 2017), the tenure (Clare et al., 2016), the superior investment skills due the level of specialization (Alda et al., 2017) or expenses (Ferruz and Alda, 2012; Broeders et al., 2019), little is known about the effect of active management and value investing strategies. To date there is no study that has evaluated the effect of both factors on the performance of pension funds.

In this paper we study the performance of pension funds according to the active and value investing strategies of the pension fund portfolio. In particular, we try to answer three important questions: Do investors get an excess return when choosing actively-managed pension funds? Does the application of criteria based on "value investing" allow extraordinary returns to be obtained? Does the consideration of the competitive advantages of the companies in the portfolio determine the level of performance?

This work contributes to the existing literature by analyzing whether active management and investment based on the fundamentals of the portfolio should be considered to identify pension funds with better future performance. Given that pension funds have a longer time horizon and different investment objectives, the results could differ from those found for mutual funds. On the other hand, we have not found any paper analyzing all the criteria considered in this article. To develop such an analysis, we have used panel data of all equity pension funds that invest in the Euro area based on the information provided by the Morningstar Direct database. In this way, we intend to evaluate the extent to which the selection of pension funds based on these criteria can help to identify those that outperform their peers' in the mid- and long- term. This study is useful for managers, financial advisers and investors interested in selecting assets.

The results obtained show how certain aspects related to the investment portfolio of the pension fund, such as management type, degree of concentration, fundamentals and competitive advantages, determine future risk-adjusted performance. Nonetheless, the relationship is non-linear, indicating that concentrated portfolios that differ from the benchmark and invest in undervalued assets in terms of price earnings ratio (PER)-return on assets (ROA) outperform their peers. 
The rest of the paper is organized as follows. In section 2 we present the empirical analysis, in section 3 we present the estimated models and the results and, finally, in section 4 we present the conclusions.

\section{The related literature and hypothesis development}

Management type has usually been seen as a possible determinant of performance, with an important literature in the field of mutual funds. Higher profitability of active management over passive management implies managers possessing selection skills. However, there are inconclusive results (Clare et al., 2009, 2010). In this sense, Grinblatt and Titman (1989, 1993) and Wermers (2000) find that in the North American market there are managers who have the ability to choose assets which provide a higher gross but not net return. In addition, the most successful managers have been regarded as lucky (according to Carhart (1997)) bearing in mind how difficult is to dissociate profitability obtained by skill and by chance (Fama and French, 2010). In addition, the distinction between active and passive management raises issues with respect to how to identify the managers that actually are active. In many cases, products that generate small changes in the composition of the index are classified as active management funds and, in this way, higher commissions could be justified. For this reason, several recent works have included active management based on the fact that its composition differs from the index and not just because a manager decides to declare their business as so. The divergence between the composition of the mutual fund and the benchmark explains the positive effect on performance in several papers (Brands et al., 2006; Kacperczyk et al., 2005 and Cremers and Petajisto, 2009). In the particular case of Cremers and Petajisto (2009), they use the active share to evaluate the degree of differentiation between the funds and the benchmark. Active share measures the proportion of assets where a fund differs from the benchmark and it indicates to what extent the manager is replicating the index. Later, Petajisto (2013) establishes denominations for funds based on active share: the stock pickers are those with shares that are far from the index and diversified, the factor bets have less diversification and are more exposed to volatility, while the concentrated funds have a large exposure to risks with a high level of screening; closet indexers try to make a slight differentiation with respect to the index, providing the least active management. The empirical results of his work show that the stock pickers have the funds that provide the best results for investors, However, Jin et al. (2016) observe that managers who are very different from the index show an excess of self-confidence that negatively affects performance and increases risk. In this sense, they consider that moderate levels of active share present better performance and in their work they showed a relationship in the form of an inverted Crane and Crotty (2018) suggest that only a small percentage of mutual funds with high Active Share outperform a passive investing strategy (index funds). An alternative measure of active management is proposed by Amihud and Goyenko (2013), who used the $R$-squared and showed that the portfolios of lower $R^{2}$ combined with higher alphas generated a higher risk-adjusted return in the next period. Elton et al. (2019) evidence that the criterion of Amihud and Goyenko (2013) resulted in a group of active funds that outperformed passive investing.

Based on previous work, we propose the following hypotheses:

H1. Active management pension funds obtain better performance (measured by the five factor Fama-French alpha).

The conviction, defined by Cremers (2017) as "the willingness to translate the identified investment opportunities into a portfolio that is sufficiently different to outperform in th longterm" is other important pillar that active managers need to bring long term economic rewards to the investors. Examples are those strategies looking for long-term underpricing.

\section{The performance of pension funds}


EJMBE 30,3
Shleifer and Vishny (1997) argue that these strategies require strong convictions because they can underperform in the short-term. According to Cremers (2017), a high active indicator is not a sufficient condition because the conviction and identification of interesting investment opportunities are necessary. Cremers and Pareek (2016) and Gonzalez et al. (2020) use the active share and a modified active share to evidence that the pension fund's performance increases if a fund has an active investment strategy and a patient strategy (long-term holdings). Therefore, active pension funds that hold long-term positions by conviction are "outperformers" and those that do a lot of trading are usually "underperformers". The concentration of the portfolio can be used as a measure of conviction because it is an indicator of the magnitude of bets taken by fund managers. The degree of concentration has been related positively with mutual fund performance (Kacperczyk et al., 2005). Also Brands et al. (2005) found a positive and significant relationship between performance and portfolio concentration for our sample of active equity mutual funds.

H2. More concentrated pension funds outperform those less concentrated.

The future profitability of pension funds may be related to the fundamental parameters of the assets of the portfolio. Value investing includes a diverse set of strategies based on the identification of undervalued assets, which have better future behavior when the market values them correctly. Among the ratios considered to identify "undervalued" assets, the market-to-book is usually included (Stattman, 1980, Rosenberg et al., 1985 or Fama and French, 1992). Pontiff and Schall (1998) show that it contains information on future profitability that is not captured by other variables. Mohanram (2005) finds that growth companies with high price-to-book ratios outperform those with low growth in future performance. Additionally, $\mathrm{Gu}$ (2015) maintains that the yields of the shares are related to characteristics of the company such as the book-to-market, PER and cash-flow-to-price among others. Likewise, Ball et al. (2020) conclude that the book-to-market is significant in explaining future returns. Piotroski and So (2013) attribute the value effect to the errors valuing the fundamentals of the company. Furthermore, Paramés (2016) explains that the shares quoted with low values in the ratios can have better future performance. As multiples, various ratios have been included, such as earnings-to-price (Basu, 1977; Reinganum, 1981), cashflow-to-price ratio (Lakonishok et al., 1994) and sales-to-enterprise-value ratio (O'Shaughnessy, 2011). In this sense, O'Shaughnessy (2011) analyzed various investment strategies, finding several options that could beat the indexes, among which he pointed out: low PER ratios, EV/EBITDA ratio compared with profit, low price/sales ratio, etc. Likewise, the value factor three strategy, which combines low values of price-to-book, PER, price/sales, EBITDA/EV, price/cashflow and repurchase of shares, outperforms the profitability of the indexes evaluated.

An alternative strategy to the search for exclusively "cheap" stocks is one proposed by Greenblatt (2006), called the "magic formula", which consists of selecting cheap securities, in terms of value (EBIT / EV), provided that they have "quality", which can be defined by the high profitability gained on the tangible capital invested [ratio EBIT / (Working Capital + net fixed assets)], which, to put it in other words, means buying cheap assets of high quality. In relative terms, one expects for profitable, quality and undervalued companies to perform better in the future. Within this value approach, shares with higher PER can be selected if they are of high quality, measured in accordance with the capacity to generate profitability. Blackburn and Cakici (2017) using a so-called "improved version" of the magic formula, which uses gross margin instead of EBIT, based on the proposal of Novy-Marx (2013), shows that in general the portfolios provided higher risk-adjusted results for all the global regions considered. Paramés (2016) explains how its investment policy is based on the application of the Greenblatt principles combined with the identification of competitive advantages in the 
mid- and long- term. This strategy is consistent with the approach of Asness et al. (2019), who consider that investment in quality companies, understood as safe and profitable, sharing growth and with well-managed assets, are those that perform better in the future.

H3. Pension funds that combine "undervaluation" (low book-to-market, PER or cashflow-to-price) and "quality" (high ROA) provide better performance. In this sense, a non-linear relationship in the form of an inverted $U$ is expected.

Finally, competitive advantages that are sustainable over time are also very relevant as they can allow future performance to be maintained. Several authors indicate the importance of competitive advantages to maintain extraordinary returns in the future (Greenblatt, 2006 and Paramés, 2016). In this sense, the Economic Moat is a term proposed by Warren Buffet that helps evaluate to what extent the assets of the portfolio have sustainable competitive advantages. Morningstar evaluates the historical capacity of companies to obtain returns above their cost of capital for many years, especially if they have increased or remained stable. The attributes of the company that can provide economic moats are, mainly, what is known as the network effect, as well as intangible assets, cost advantages, exchange costs and economies of scale. Kanury and Mcleod (2016) found that portfolios with wide moat outperform the S\&P 500 and Russell 3,000 indices in terms of several measures of performance, including Carhart four-factors model. Based on previous work, we propose the following hypotheses regarding the effect of management on performance:

H4. Pension funds with a higher Economic Moat provide better ex-post performance.

\section{Empirical study}

\subsection{Sample}

Our sample is composed of all the pension funds active in the period 2000 to 2017 [1]. In order to have a homogeneous database, we selected exclusively pension funds investing in the Eurozone [2]. What this means is that a greater similarity is guaranteed in terms of benchmark, assets available for investment and currency. Considering the investment style, more than $48 \%$ are large blended capitalization pension funds, compared to $36.6 \%$ for value funds and $9.41 \%$ for growth funds. The rest $(4.7 \%)$ belongs to different styles of mid and small caps. Regarding country of residence, it should be emphasized that more than $80 \%$ were domiciled in Spain and Belgium, with a minority representation for the United Kingdom, Ireland and Luxembourg, among others. Depending on the year, the number of pension funds can range from 39 (like in 2000) up to 103 (like in 2010) and for many variables the information is available from 2007. All the data has been retrieved from the Morningstar Direct database.

\subsection{Performance variables}

We analyze the performance of pension funds in terms of risk-adjusted return, using a fivefactor model proposed by Fama and French (2015, 2016, 2017). The alpha is estimated annually via the following regression model (Eqn (1)):

$$
R_{i, t-} R_{f, t}=\alpha_{i}+\beta_{i, 1} M k t_{t}+\beta_{i, 2} S M B_{t}+\beta_{i, 3} H M L_{t}+\beta_{i, 4} R M W_{t}+\beta_{i, 4} C M A_{t}+\varepsilon_{i, t}
$$

where $R_{i, t}$ is the performance of the fund $i$ in month $t, R_{f}$ is the yield of the risk-free asset in month $t ; M k t_{t}$ is the average monthly return of the benchmark minus the risk-free interest rate; $S M B_{t}$ considers the exposure to returns of diversified portfolios of small and large companies; $H M L_{t}$ takes into account the difference between the yields of portfolios with high and low book-to-market; $R M W_{t}$ is the difference between the returns of the portfolio of assets with robust profitability, compared to assets with weak profitability; CMAt is the difference 
EJMBE 30,3

\section{4}

between the yields of aggressive portfolios versus conservators and, finally $\varepsilon_{i, t}$ is the error term. The parameters $\beta_{i}$ measure the sensitivity of the excess performance to each risk factor.

Therefore, the performance of a fund conditioned to all the risk factors can be evaluated with the alpha given by the parameter $\alpha_{i}$ of the above equation. For each year, we estimate the regression model for all individual pension funds, using weekly prices information. Subsequently, we computed yearly alphas based on the following expression: $\alpha_{\text {yearly }}=\left(1+\alpha_{\text {weekly }}\right)^{n}-1$, where $n$ is the number of trading weeks in each year. We have also used the alpha of three and four factors as alternative measures. The data used to estimate the alphas have been extracted from the Morningstar database and from Professor Kenneth R. French's website [3].

\subsection{Independent variables}

As explanatory variables related to management type, we have included $R$-squared as an indicator of active management (Table 1). This variable has been used in several mutual funds papers, highlighting that of Amihud and Goyenko (2013). In addition, the level of concentration in the 10 main assets of the portfolio (Assets10_) has been included in line with Cremers' approach (2017) and the total number of shares (Holdings_) to consider whether the fund invests in few assets or if it diversifies into many of them.

Relating to the fundamentals of the investment portfolio, several ratios have been included that are usually considered predictors of future performance, in particular, market-to-book (Gu, 2015; Ball et al., 2020), where a positive relationship is expected with the excess of return. Likewise, the price earnings ratio (PER) (Basu, 1977; Reinganum, 1981) and the Price-to-Free Cash Flow (PtoFCF) used in the work of O'Shaughnessy (2011) have been included. As a quality indicator we have incorporated return on assets (ROA), used by Greenblatt (2006). Finally, the Economic Moat (Moat) calculated by Morningstar and linked to the portfolio percentage with sustainable competitive advantages has been added.

Several control variables have traditionally been used, such as the percentage-of-expenses (Expenses), net-flow-over-total-assets (NetflowTA), volatility (LossDev), fund size (NetAssets_) and gross return (Return_). For more information, see the recent works of El Ghoul and Karoui (2017) and Armstrong et al. (2017).

\begin{tabular}{|c|c|c|}
\hline Variable & Sign & Source \\
\hline \multicolumn{3}{|c|}{ Dependent variables } \\
\hline $\mathrm{R}_{-}^{2}$ & - & Morningstar Direct \\
\hline Assets10 & + & Morningstar Direct \\
\hline Holdings_ & - & Morningstar Direct \\
\hline PtoBook & + & Morningstar Direct \\
\hline ROAPER_ & - & Morningstar Direct \\
\hline PtoFCF_ & - & Morningstar Direct \\
\hline $\mathrm{ROA}_{-}$ & + & Morningstar Direct \\
\hline Moat_- & + & Morningstar Direct \\
\hline \multicolumn{3}{|c|}{ Control variables } \\
\hline Expenses__ & - & Morningstar Direct \\
\hline NetflowTA & + & Morningstar Direct \\
\hline LossDev_ $_{-}$ & - & Morningstar Direct \\
\hline NetAssets_ & + & Morningstar Direct \\
\hline Return_ & - & Morningstar Direct \\
\hline
\end{tabular}

Table 1.

Variables and hypothesis 
Table 2 summarizes the main variables. As can be seen, risk-adjusted performance has a negative mean value, albeit close to zero, with noticeable differences in variation. If we analyze the alphas, we can observe that, on average, the pension funds do not beat the market index, although there are a certain proportion that do. The return without riskadjustment (Return) shows the level of risk that investors have assumed at specific times and assets, with losses and gains that exceed 50\%. Regarding the rest of the explanatory variables, those related to management type show moderate values of $R^{2}(71.40)$ [4] which indicates a high percentage of closet indexer strategies, tracking the index with small variations with respect to it. The portfolios concentrate an average of $50 \%$ of the assets in the 10 main securities, but they invest in approximately 60 different assets. The fundamentals of the portfolios have average PER values of around 14 years and ROA of $4.31 \%$, while the indicator of competitive advantages has an average value of 11 , which highlights, following the Morningstar methodology that, on average, the companies included in the portfolios do not have competitive advantages in the long term. The pension funds evaluated have experienced net outflows, have a volatility of $12 \%$ and handle 18.7 million euros.

Most of the previous analysis (negative mean alphas, moderate values of $R^{2}$, medium portfolio concentration, etc.) hold for the different temporary sub-periods considered in Table 2. However, obviously the behavior of the flows and returns do vary in the different sub-periods considered.

\section{Models}

In this section we detail the models employed to measure the level of performance of the fund in year $t$ explained by the variables analyzed above. The impossibility of having a complete database for all the factors must be underlined because the inclusion of many variables would imply a considerable reduction in sample size. This has motivated to build independent models for active management and fundamentals, using common control variables and, finally in the robustness test, to show an overall model. Following the works of El Ghoul and Karoui (2017) and Armstrong et al. (2017) we estimate panel data models. The GMM model was used to estimate the regression between performance and independent variables. System GMM dealt well with independent variables that were not strictly exogenous, i.e. they correlated with past and possibly current realizations of the error, with fixed effects, heteroscedasticity and autocorrelation within individuals (Roodman, 2009).

\subsection{Models for the level of active management}

In this section we detail the model used to estimate the effect of active management versus passive management on performance. Following Amihud and Goyenko (2013), we use the $R^{2}$ of the regression of the return on the index in such a way that the most active funds are those that have a lower value. As can be seen in Table 3 , more than $50 \%$ of the funds have an $R^{2}$ close to $90 \%$, which implies rather passive management in a high percentage of pension funds. However, more than $25 \%$ opt for portfolios that differ substantially from the benchmark.

Another interesting feature is related with the degree of concentration and the number of assets of the pension fund portfolio. As we can see in Table 4, pension funds concentrate a notable proportion of their investments' portfolio in 10 shares. However, it is also observed that in general the number of assets exceeds 55 in more than $50 \%$ of the portfolios, which implies that it also diversifies through a broader number of securities. 


\section{EJMBE 30,3}

306
Table 2.

Summary of statistics

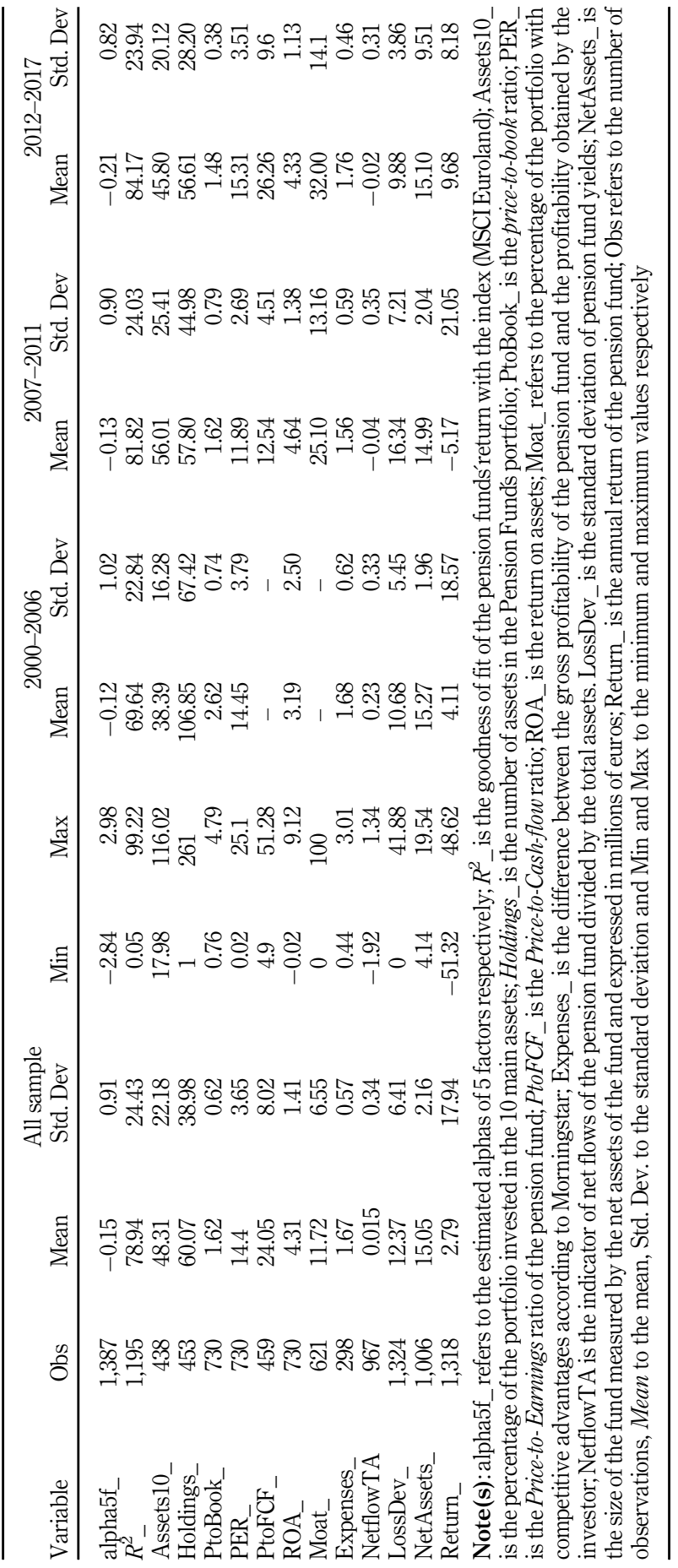


In order to evaluate the relationship between management type and the performance of the pension funds, we estimate the following model (Eqn (2)):

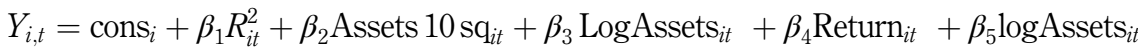

$$
\begin{aligned}
& +\beta_{5} \operatorname{LossDev}_{i t}+\beta_{6} \text { NetflowTA }_{i t}+\sum \text { style }+\sum \text { year }+\varepsilon_{i t}
\end{aligned}
$$

where:

$Y_{i}=$ Alpha.

$i=1$ to $N$, where $N$ is the number of mutual funds in the sample.

$R^{2}=R$ squared of the regression between the returns of the fund and the index.

Assets $10=$ Proportion invested in the 10 main assets.

$\operatorname{logHoldings}=$ Logarithm of the number of securities in the portfolio

Return $=$ Annual net return.

LogAssets $=$ Size of the pension fund measured by total assets.

LossDev $=$ standard deviation of the returns.

NetflowTA $=$ Net flows over total assets.

Style $=$ Investment style.

Year $=$ Time Dummies.

cons $_{i}$ and $\beta$ are the parameters of the regression $\varepsilon_{i t}$ the error term.

\begin{tabular}{lr}
\hline Probability & Percentile \\
\hline 0.05 & 1.16927 \\
0.1 & 5.47632 \\
0.25 & 55.03145 \\
0.5 & 88.85685 \\
0.75 & 96.75473 \\
0.9 & 98.05594 \\
0.95 & 98.48854 \\
0.99 & 99.01876
\end{tabular}

Table 3. $R^{2}$ distribution for pension funds

\begin{tabular}{lccr}
\hline Percentile & Concentration in the 10 main assets & Number of assets & \\
\cline { 1 - 2 } 5 & 28.59 & 9 & \\
10 & 31.58 & 13 & \\
25 & 35.36 & 46 & \\
50 & 40.21 & 55 & Table 4. \\
75 & 49.04 & 62 & Portfolio concentration \\
90 & 97.44 & 90 & and number of assets \\
95 & 100.00 & 144 & \\
\hline
\end{tabular}


EJMBE 30,3

\section{8}

Table 5.

Active management and performance

\subsection{Models considering value investing strategies}

In this section we comment the model employed to relate the effect that the fundamentals of the pension fund portfolio have on future performance. Again, there are important differences in the ratios of the portfolios; in other words it is possible to carry out strategies based on fundamental criteria (Table 6).

To evaluate the relationship between the fundamental ratios and the performance of pension funds, we estimate several models, combining several ratios with quality criteria and competitive advantages. First of all we estimate the combination of the PER with the value ratios (Eqn (3)):

\begin{tabular}{lccc}
\hline Variable & Model 1 & Model 2 & Model 3 \\
\hline alpha5f_(T-1) & -0.0294 & $-0.2264^{* * * *}$ & $-0.1989^{* * * *}$ \\
$R^{2}(\mathrm{~T}-1)$ & $-0.0048^{*}$ & - & $-0.0087^{* * *}$ \\
Assets10 & - & $0.0054^{* * * *}$ & $0.0045^{* *}$ \\
logHoldings & - & 0.0323 & 0.0253 \\
Return_ & $0.0750^{* * *}$ & $0.0724^{* * * *}$ & $0.0779^{* * * *}$ \\
Logassets & -0.0395 & $-0.0692^{*}$ & -0.0362 \\
LossDev_- & $0.0348^{* *}$ & $0.1261^{* * *}$ & $0.1300^{* * *}$ \\
NetflowTA & 0.0292 & 0.2993 & 0.2616 \\
Largeblend & -0.8275 & -0.1395 & 0.2018 \\
Largegrowth & -0.9052 & -0.2162 & 0.4102 \\
Largevalue & $-1.1145^{*}$ & -0.1941 & 0.4669 \\
cons & 0.0000 & 1.4029 & 0.0000 \\
$N$ & 689 & 279 & 276 \\
hansen & 59.4903 & 43.1437 & 44.7197 \\
ar2 & 0.296 & -1.81 & -1.9414
\end{tabular}

Note(s): This table contains the GMM regression parameter values between the 5 -factor Alphas and a set of explanatory variables. $R^{2}$ is the coefficient of regression determination between the profitability of the fund and the index, Assets10 is the percentage invested in the 10 main securities, logHoldings is the logarithm of the number of holdings, Return is the net return and Logassets is the logarithm of the size in euros of the pension fund, LossDev_ is the volatility of the fund, NetflowTA is the percentage that the net flows represent over the total assets. Largeblend, Largegrowth and Largevalue are dummies for the investment style of the fund. The model has been estimated including temporary dummies that are not shown in the results. $N$ refers to the number of observations. Hansen is a test for overidentifying restrictions and AR2 is the autocorrelation test. Legend: ${ }^{*} p<0.1 ;{ }^{* * *} p<0.05 ;{ }^{* * *} p<0.01$

\begin{tabular}{lcrrr}
\hline Percentile & PtoBook & Per $_{-}$ & PtoFCF_ & ROA_ \\
\hline 1 & 0.91 & 5.61 & 4.90 & 0.11 \\
5 & 1.06 & 9.04 & 10.35 & 1.93 \\
10 & 1.12 & 10.31 & 12.40 & 3.07 \\
25 & 1.27 & 11.54 & 18.18 & 3.82 \\
50 & 1.44 & 14.65 & 24.23 & 4.17 \\
75 & 1.66 & 17.24 & 31.08 & 4.95 \\
90 & 2.46 & 18.96 & 34.92 & 6.05 \\
95 & 3.22 & 18.96 & 37.59 & 8.64 \\
99 & 3.97 & 22.10 & 62.58 & 8.41
\end{tabular}

Table 6.

Ratios of the Pension Funds' portfolios
Note(s): In this table PtoBook is the Price-to-Book ratio, $\mathrm{PER}$ is the Price-to-Earnings Ratio, PtoFCF is the Priceto-free cash flow and ROA is the return on assets 


$$
\begin{aligned}
Y_{i, t}= & \text { cons }_{i}+\beta_{1} \operatorname{ROAPER}(t-1)_{i t}+\beta_{2} \operatorname{ROAPERsq}_{i t}+\beta_{3} \operatorname{Return}_{i t} \beta_{4} \log \operatorname{Assets}_{i t} \\
& +\beta_{5} \operatorname{LossDev}_{i t}+\beta_{6} \text { NetflowTA }_{i t}+\sum \text { style }+\sum \text { year }+\varepsilon_{i t}
\end{aligned}
$$

where:

$$
Y_{i}=\text { Five factor Alpha }
$$

$i=1$ to $N$, where $N$ is the number of pension funds in the sample.

ROAPER $=$ Interaction variable of the product of Roa and the Price-Earning Ratio. We also estimate the same interaction variables with PtoFCF and PtoBook.

ROAPERsq $=$ ROAPER squared

Return $=$ Annual net return.

LogAssets $=$ Size of the pension fund measured by total assets.

LossDev $=$ Standard deviation of the returns.

NetflowTA $=$ Net flows over total assets.

Style $=$ Investment style.

Year $=$ Time dummies.

cons $_{i}$ and $\beta$ are the parameters of the regression and $\varepsilon_{i t}$ is the error term.

\section{Results}

In this section we show the results of the level of performance of the fund in year $t$ explained by the variables analyzed above and the previous models [5].

\subsection{Results for the level of active management}

Our findings from the estimation of Eqn (2) (Table 5) support hypothesis 1, which poses a positive relationship between active management and future performance. In fact, in all the models (Model I, II and III) we have found in the specific case of our sample that the pension funds that differ from the index (low $R$-squared) are those that achieve better alphas. Therefore, the divergence of the portfolio of equity pension funds with the Eurozone Investment Area has a positive effect on performance in line with previous work on mutual funds (Brands et al., 2006; Kacperczyk et al., 2005; Cremers and Petajisto, 2009). Additionally, regarding the work of Amihud and Goyenko (2013), we find that the funds portfolios with lower $R$-squared value generate a higher alpha in the next period. The estimated regression model also shows how the concentration strategy has a positive impact in line with hypothesis 2 . In this way, those strategies that choose to invest a relevant part of the portfolio in a low number of assets achieve better future performance (Table 5). These findings are in accordance with those obtained for mutual funds and support the existence of selection skills and convictions in some managers (stock pickers) that provide the best results for investors (Petajisto, 2013). Recently, Cremers (2017) has maintained that only the mutual funds that differ from the indices and have "convictions" are able to beat the market, that is, they are "outperformers", and those that do a lot of trading generally obtain lower returns, therefore being "underperformers". This result is also support from the pension fund's previous literature. Cremers and Pareek (2016) and Gonzalez et al. (2020) find that the pension fund's performance increases if a fund is patient and has an active investment strategy. 
EJMBE 30,3

\section{0}

Table 7.

Value investing and performance
Regarding the number of assets, the relationship is not significant. What that means is that the strategy of concentrating on a few assets and differentiating the portfolio from the index seems to give good results.

\subsection{Results considering value investing strategies}

Table 7 shows the results of several regressions using the main value and profitability ratios as explanatory variables and Eqn (3). The models have been combined to avoid multicollinearity problems detected due to the important correlation between some of them. Following the approach of Greenblatt (2006) and Blackburn and Cakici (2017), if the quality of the business is good, the combination of price and quality may justify paying more for the securities. For this reason, we use an interaction variable and its square, assuming that there is a non-linear relationship, since higher relative prices can be paid if the quality of the business, as measured by the ROA, is reasonable, but to a level from which the effect is reduced. In line with this approach, we see that the interactions of the PER and the ROA as well as the square are significant, which implies that funds that pay higher prices can have a positive effect on the alpha, although after a certain level the effect is reduced. Analyzing the distribution of the values of PER and ROA, we observe that the best combinations are those of high ROA combined with PER above the average. Evaluating the distribution of the variable ROAPER we observe that less than $5 \%$ of the pension funds have values close to the maximum. This implies that a strategy which consists of paying more for assets of higher quality can have positive consequences in terms of Excess Return as explained in

\begin{tabular}{|c|c|c|c|c|c|c|}
\hline Variable & Model1 & Model2 & Model3 & Model4 & Model5 & Model6 \\
\hline pha5f & $-0.1967^{* *}$ & $-0.2618^{\text {***** }}$ & $-0.2012^{\text {**** }}$ & $-0.2203^{\text {***** }}$ & $-0.2321^{* *}$ & $-0.2277^{* * * * *}$ \\
\hline DAPER (T-1) & 0.0223 & - & - & $0.0251^{* * * *}$ & - & - \\
\hline OAPERsq (T-1) & $-0.0001^{* * * *}$ & - & - & $-0.0001^{* * * *}$ & - & - \\
\hline OAPtoFCl & - & $0.0058^{* * *}$ & - & - & $0.0055^{* *}$ & - \\
\hline (T-1) & - & 0.0000 & - & - & 0.000000 & - \\
\hline $\mathrm{RoaPt}$ & - & - & 0.0442 & - & - & 0.0982 \\
\hline oaPtol & - & - & -0.0002 & - & - & -0.0043 \\
\hline Ioa & - & - & - & -0.0043 & -0.0006 & -0.0025 \\
\hline & $0.0617^{* * * *}$ & $0.0715^{* * * *}$ & $0.0611^{* * * *}$ & $0.0595^{* * * *}$ & $0.0731^{* * * *}$ & $0.0614^{* * * *}$ \\
\hline Logassets & -0.0045 & 0.017 & -0.0127 & 0.00 & 0.0117 & 0.0106 \\
\hline LossDev_ $_{-}$ & $0.1078^{* * * *}$ & $0.1164^{* * * *}$ & $0.1025^{* * * *}$ & $0.1182^{* * * * *}$ & $0.1159^{* * * *}$ & $0.1146^{* * * *}$ \\
\hline Net & & 0.1347 & 0.0253 & & 0.1779 & 0.0156 \\
\hline Largeblend & 0.0322 & -0.3854 & 0.026 & -0.1898 & -0.2993 & -0.2099 \\
\hline Largegrowth & -0.2159 & $-0.6542^{* * *}$ & -0.2825 & $-0.4893^{*}$ & $-0.5814^{* * *}$ & -0.4249 \\
\hline Largevalue & 0.0259 & $-0.4657^{*}$ & 0.0128 & -0.2379 & -0.4038 & -0.1904 \\
\hline _cons & -1.224 & $-1.8401^{* * * *}$ & 0 & $-5.3749^{* * * *}$ & $-1.6734^{* *}$ & $-2.9528^{* * * *}$ \\
\hline $\bar{N}$ & 357 & 242 & 357 & 324 & 241 & 324 \\
\hline han & 0.998 & 0.971 & 0.95 & 0.962 & 0.967 & 0.887 \\
\hline $\operatorname{ar} 2$ & -0.2999 & -1.7373 & -0.2455 & -0.1944 & -1.5488 & -0.5256 \\
\hline
\end{tabular}

Note(s): This table contains the values of the GMM regression parameters among the five- factor alphas and a set of explanatory variables. ROAPER is the interaction variable of the product of Roa and the Price-Earning Ratio and ROAPERsq is the ROAPER squared. ROAPtoFCF is the product of ROA and the Price to FCF and ROAPtoFCFsq is the square of ROAtoFCF. Roaptobook is the product interaction variable of the product of Roa and Price-to-Book and RoaPtobooksq is its squared value. Return is the net return and Logassets is the logarithm of the size in euros of the pension fund. LossDev_ is the volatility of the fund, while NetflowTA is the percentage that the net flows represent over total assets. Largeblend, Largegrowth and Largevalue are dummies for the investment style of the fund. The model has been estimated including temporary dummies that are not shown in the results. $N$ refers to the number of observations, Hansen is a test for overidentifying restrictions and AR2 is the autocorrelation test. Legend: ${ }^{*} p<0.1 ;{ }^{* *} p<0.05 ;{ }^{* * *} p<0.01$ 
hypothesis 4 . In the case of the interaction of the price-to-cash flow with Roa, only the linear coefficient is significant and price-to-book is not significant at all.

In addition, from models 4 to 6 we have included the Economic Moat provided by Morningstar to consider the effect of sustainable competitive advantages on future performance. The results of incorporating the economic moat in the previous models, which only included fundamental criteria, show that the variable is not significant in any of the three models (Table 7). Therefore, the consideration of value strategies based on companies with a good price-quality ratio seem to be a good strategy for reaping extraordinary returns, although the economic moat is not significant.

\section{Robustness}

In order to check the robustness of our findings, we included Table 8 (second column) with all the variables that were significant in the previous models and using the same period for the analysis (2007-2017). We can observe that the main variables indeed remain significant, showing the importance of these factors for explaining the performance of pension funds regardless of the period considered. Only the variable Assets10 is not significant in the overall model although the sign does not change. Table 8 (third column) show the results of the same previous estimation using dummies for pension funds of Spain and Belgium, main variables indeed remain significant (only alphas results in this case not significance) This analysis allows us to overwhelm the challenges indicated by Ferson (2010) considering various regulatory context, competition, etc.

We have also recalculated the model using a Random Effects panel data model. As we can see in Table 9, the variables that are significant in the dynamic model remain so in the new estimated ones. In addition, the signs of the latter's coefficients are unchanged from the former's. The use of dummies for the most represented countries (Spain and Belgium) (third column of Table 9) induce similar results.

As can be seen in Table 10, all the coefficients in the hypothesis 1,2 and 4 are significant and in line with our expectations. In general, the degree of active management the portfolio concentration and a good balance between Price and quality, measured by the interaction of

\begin{tabular}{|c|c|c|}
\hline Variable & Overall & Dummies country \\
\hline alpha5f & $-0.2403^{\text {**** }}$ & -0.0191 \\
\hline$R_{-}^{2}$ & $-0.0167^{* * *}$ & $-0.0131^{*}$ \\
\hline Assets10 & 0.0013 & 0.0003 \\
\hline ROAPER & $0.0559^{* *}$ & $0.0483^{\text {**** }}$ \\
\hline ROAPERsq & $-0.0004^{*}$ & $-0.0004^{* *}$ \\
\hline Return_ & $0.0820^{* * * *}$ & $0.0659^{* * * *}$ \\
\hline Logassets & -0.0382 & -0.0272 \\
\hline LossDev & $0.1604^{* * * *}$ & 0.092 \\
\hline NetflowTA & 0.6278 & 0.4732 \\
\hline Largeblend & 0.1933 & 0.4221 \\
\hline Largegrowth & 0.0604 & 0.1873 \\
\hline Largevalue & 0.283 & 0.4388 \\
\hline Spain & & -0.0689 \\
\hline Belgium & & 0.0000 \\
\hline cons & 0.6019 & -1.533 \\
\hline $\bar{N}$ & 227 & 227 \\
\hline hansen & 0.991 & 0.972 \\
\hline ar2 & -1.11 & -0.91 \\
\hline
\end{tabular}

Note(s): See Tables 5 and 7

performance of pension funds 


\section{EJMBE \\ 30,3}

Variable Random effects

Dummies country

$R^{2}$

Assets10

ROAPER

ROAPERsq

Return

Logassets

LossDev_

NetflowTA

Largeblend

Largegrowth

Largevalue

Table 9.

Model considering all the significant variables

- cons

$$
\begin{gathered}
-0.0117^{\text {**** }} \\
0.0007^{\text {**** }} \\
0.0447^{\text {*** }} \\
-0.0003^{\text {***** }} \\
0.0578^{\text {*** }} \\
0.0031 \\
0.0442 \\
0.2153 \\
0.2142 \\
-0.0193^{\text {* }} \\
0.2777^{\text {** }} \\
0.000 \\
227 \\
0.7173
\end{gathered}
$$$$
\text { r2_o }
$$

$$
\begin{gathered}
-0.0125^{\text {**** }} \\
0.0009^{\text {**** }} \\
0.0448^{\text {*** }} \\
-0.0003^{\text {*** }} \\
0.0595^{\text {**** }} \\
0.0005 \\
0.0487 \\
0.1939 \\
0.2658^{*} \\
0.0781^{\text {***** }} \\
0.3299^{*} \\
0.0482^{*} \\
-0.4151^{*} \\
-1.8306^{\text {*** }}
\end{gathered}
$$

Note(s): See Tables 5 and 7

Hypothesis

$\begin{array}{ll}\text { H1 } & \text { Sign } \\ & \text { Significant } \\ \text { H2 } & \text { Sign } \\ & \text { Significant } \\ \text { H3 } & \text { Sign } \\ & \text { Significant } \\ \text { H4 } & \text { Sign } \\ & \text { Significant }\end{array}$

Results

Yes

$+$

U inverted

Yes

$\stackrel{+}{\text { No }}$
Table 10.

Summary results of Testing Hypothesis
Figure 1.

Performance and ROA to PER relationship



Roa and PER, has a positive effect on pension funds performance. Also, the number of assets and the economic moat were not significant.

Finally, we use the three-factor alpha and the four-factor alpha instead of the five-factor alpha in the previous estimations. The results achieved are very similar to those obtained in the case of the alpha of five factors. 


\section{Conclusions}

The objective of this study is to analyze the effect of management type and the fundamentals of the investment portfolio on future performance. For this purpose, we use a sample composed of pension funds that invest in the Euro area and for which historical information exists for the period 2000-2017. In this way, it is a matter of seeing to what extent certain characteristics of pension funds serve to identify products that will perform better than their competitors and if they can really provide an excess of return.

The management type variable (Active / Passive) has yielded positive results in favor of portfolios that differ from the index. Likewise, the estimated regression model shows how the concentration strategy has a positive impact, supporting the strategies that choose to invest a relevant part of the portfolio in a few assets. This result could be related to the work of Gonzalez et al. (2020), Cremers and Pareek (2016) for pension funds or Cremers (2017) for mutual funds who believe that patient investment in assets, carried out by the manager who has a conviction in them, will provide better future performance. Likewise, the use of fundamental analysis criteria yields interesting results. The investment of funds with a balance between rice (PER or price to free cash flow, PtoFCF) and quality (measured by the $\mathrm{ROA}$ ) is the strategy that provides the best results. Therefore, compared to the most basic strategy, which consists of investing in cheap assets, the results support more expensive portfolios in terms of PER and PtoFCF and with high quality measured by the ROA; measure this in terms of the ROA. Finally, including the competitive advantages of the companies that make up the fund's portfolio has no effect on future results. As a result, it is confirmed that the selection of funds based on "Value Investing" can have a positive impact on future performance. Our results provide some light to the debatable when a growth or value style generates more wealth creation in the long term in the pension industry (see Sorensen and Fabozzi, 2008).

By way of conclusion, our research identifies factors that may be considered in the process of selecting pension funds. These results are useful for investors, financial advisors and product distributors interested in selecting the best assets in order to supplement the public pension with complementary saving products. We are aware of the different metrics that could be used to measure active management. Future research is necessary in relation to the effect of using different measures of risk-adjusted performance and alternative active management measures, such as active share. Finally, the use of more heterogeneous samples with a greater number of funds between different countries would help to confirm that the results are extensible to countries with different regulatory environments, competition, etc.

Future research will benefit from the Regulation of the European Parliament 2019/1238, of June 20, 2019 deals with the Pan-European Personal Pension Product (PEPP). EU member countries have a period to transpose it into their legal systems until June 2022 (three years from its approval). With the new Regulation, there will be a true single market for personal pensions and an EU passport to facilitate cross-border distribution. New regulation will impulse competition in returns and a reduction in fees due to greater economies of scale. For the research community, this new single market will allow a new category of equivalent pension fund products to which the analyzes carried out previously should be extended.

\section{Notes}

1. For the models of fundamental analysis we use exclusively the information comprised between 2007-2017 because the data for most of the variables is only available for this period.

2. To be included in our sample, funds must be at least 12 months old to avoid the incubation bias. To prevent survivorship bias, we consider all mutual funds that meet the following criteria (surviving and not surviving funds): "Insurance and Pension Funds" with Global category "Europe Equity performance of pension funds 
EJMBE 30,3

\section{4}

Large Cap" or "Europe Equity Mid/Small Cap", which produces more than 2,000 funds (primary class, surviving or not surviving). In these funds there are Exchange-Traded Funds, Open-End Fund, etc. We restrained our results to Insurance Product Funds and focus on funds that belong annually to the Morningstar Category EAA Insurance Eurozone Equity Large, Medium and Small Cap (to control currency effects on returns), obtaining the final sample (125 pension funds domiciled in Europe).

3. Fama/French (FF) European Factors are available at http://mba.tuck.dartmouth.edu/pages/faculty/ ken.french/data_library.html. Weekly returns from which we calculate alphas are expressed in dollars. Since FF factors are from the perspective of an American investor, we express the five factor alpha calculated in dollars to euros using the official exchange rates (data from Morningstar, original source ECB).

4. The estimation of alphas, betas and $R^{2}$ has been done through regressions using weekly returns and a rolling window of 52 weeks.

5. All the effects of the variables depend on the market, the geographical area and other external factors.

\section{References}

Aglietta, M., Brière, M., Rigot, S. and Signori, O. (2012), "Rehabilitating the role of active management for pension funds", Journal of Banking and Finance, Vol. 36, pp. 2565-2574.

Alda, M. (2016), "Manager characteristics and manager-replacement: how is pension fund performance affected?", Czech Journal of Economics and Finance (Finance a uver), Vol. 66 No. 2, pp. 161-180.

Alda, M., Andreu, L. and Sarto, J.L. (2017), "Learning about individual managers' performance in UK pension funds: the importance of specialization", The North American Journal of Economics and Finance, Vol. 42, pp. 654-667.

Amihud, Y. and Goyenko, R. (2013), "Mutual fund's R2 as predictor of performance”, Review of Financial Studies, Vol. 26 No. 3, pp. 667-694.

Andonov, A., Bauer, R. and Cremers, K.J.M. (2012), "Can large pension funds beat the market? Asset allocation, market timing, security selection and the limits of liquidity", available at SSRN. doi: 10.2139/ssrn.1885536.

Armstrong, W.J., Genc, E. and Verbeek, M. (2017), "Going for gold: an analysis of morningstar analyst ratings”, Management Science, Vol. 60 No. 5, pp. 2310-2327.

Asness, C.F., Frazzini, A. and Pedersen, L.H. (2019), "Quality minus junk", Review of Accounting Studies, Vol. 24, pp. 34-112.

Ball, R., Gerakos, J.J., Linnainmaa, J.T. and Nikolaev, V.V. (2020), "Earnings, retained earnings and book-to-market in the cross section of expected returns", Journal of Financial Economics, Vol. 135 No. 1, pp. 231-254.

Basu, S. (1977), "Investment performance of common stocks in relation to their price-earnings ratios: a test of the efficient market hypothesis", The Journal of Finance, Vol. 32 No. 3, pp. 663-682.

Bergstresser, D., Chalmers, J.M.R. and Tufano, P. (2009), “Assessing the costs and benefits of brokers in the mutual fund industry", Review of Financial Studies, Vol. 22 No. 10, pp. 4129-4156.

Blackburn, D.W. and Cakici, N. (2017), "Overreaction and the cross-section of returns: international evidence”, Journal of Empirical Finance, Vol. 42, pp. 1-14.

Blake, C. and Morey, M. (2000), "Morningstar ratings and mutual fund performance", Journal of Financial and Quantitative Analysis, Vol. 35 No. 3, pp. 451-483.

Blake, D., Lehmann, B.N. and Timmermann, A. (1999), "Asset allocation dynamics and pension fund performance", The Journal of Business, Vol. 72 No. 4, pp. 429-461.

Brands, S., Brown, S.J. and Gallagher, D.R. (2005), "Portfolio concentration and investment manager performance”, International Review of Finance, Vol. 5 Nos 3-4, pp. 149-174. 
Brands, S., Gallagher, D.R. and Looi, A. (2006), "Active investment manager portfolios and preferences for stock characteristics", Accounting and Finance, Vol. 46 No. 2, pp. 169-190.

Broeders, D., van Oord, A. and Rijsbergen, D.R. (2019), "Does it pay to pay performance fees? Empirical evidence from Dutch pension funds", Journal of International Money and Finance, Vol. 93, pp. 299-312.

Carhart, M.M. (1997), "On persistence in mutual fund performance”, The Journal of Finance, Vol. 52 No. 1, 1997, pp. 57-82.

Chotivetthamrong, C. (2015), "The performance of Thai mutual funds: a 5-star morningstar mutual fund rating", Journal of Economics, Business and Management, Vol. 3 No. 1, pp. 104-110.

Clare, A.D. and Motson, N. (2009), "Locking in the profits or putting it all on black? An empirical investigation into the risk-taking behavior of hedge fund managers", The Journal of Alternative Investments, Vol. 12 No. 2, pp. 7-25.

Clare, A., Nitzsche, D. and Cuthbertson, K. (2010), "An empirical investigation into the performance of UK pension fund managers", Journal of Pension Economics and Finance, Vol. 9 No. 4, pp. 533-547.

Clare, A., Sherman, M.B. and Thomas, S. (2016), "Multi-asset class mutual funds: can they time the market? Evidence from the US, UK and Canada", Research in International Business and Finance, Vol. 36, pp. 212-221.

Coggin, T.D., Fabozzi, F.J. and Rahman, S. (1993), "The investment performance of U.S. Equity pension fund managers: an empirical investigation”, The Journal of Finance, Vol. 48 No. 3, pp. 1039-1055.

Crane, A. and Crotty, K. (2018), "Passive versus active fund performance: do index funds have skill?", Journal of Financial and Quantitative Analysis, Vol. 53 No. 1, pp. 33-64.

Cremers, M. (2017), "Active share and the three pillars of active management: skill, conviction, and opportunity”, Financial Analysts Journal, Vol. 73 No. 2, pp. 61-79.

Cremers, M. and Pareek, A. (2016), "Patient capital outperformance: the investment skill of high active share managers who trade infrequently", Journal of Financial Economics, Vol. 122 No. 2, pp. 288-306.

Cremers, M. and Petajisto, A. (2009), "How active is your fund manager? A new measure that predicts performance", Review of Financial Studies, Vol. 22 No. 9, pp. 3329-3365.

El Ghoul, S. and Karoui, A. (2017), "Does corporate social responsibility affect mutual fund performance and flows?”, Journal of Banking and Finance, Vol. 77 No. issue C, pp. 53-63.

Elton, E.J., Gruber, M.J. and de Souza, A. (2019), "Are passive funds really superior investments? An investor perspective", Financial Analysts Journal, Vol. 75 No. 3, pp. 7-19.

Fama, E.F. and French, K.R. (1992), "The cross-section of expected stock returns", The Journal of Finance, Vol. 47 No. 2, pp. 427-465.

Fama, E.F. and French, K.R. (2010), "Luck versus skill in the cross-section of mutual fund returns", The Journal of Finance, Vol. 65 No. 5, pp. 1915-1947.

Fama, E.F. and French, K.R. (2015), "A five-factor Asset pricing model”, Journal of Financial Economics, Vol. 116, pp. 1-22.

Fama, E.F. and French, K.R. (2016), "Dissecting anomalies with a five-factor model", Review of Financial Studies, Vol. 29, pp. 70-103.

Fama, E.F. and French, K.R. (2017), "International tests of a five-factor Asset pricing model”, Journal of Financial Economics, Vol. 123, pp. 441-463.

Ferruz, L. and Alda, M. (2012), "The role of fees in pension fund performance. Evidence from Spain", Czech Journal of Economics and Finance, Vol. 62 No. 6, pp. 518-535.

Ferson, W.E. (2010), "Investment performance evaluation”, Annual Review of Financial Economics, Vol. 2, pp. 207-234. 
EJMBE 30,3

Gonzalez, T.A., van Lelyveld, I. and Lucivjanska, K. (2020), "Pension fund equity performance: patience, activity or both?", Journal of Banking and Finance, Vol. 115, pp. 1-16.

Greenblatt, J. (2006), The Little Book that Beats the Market, Wiley, NJ.

Grinblatt, M. and Titman, S. (1989), "Mutual fund performance: an analysis of quarterly portfolio holding”, Journal of Business, Vol. 62 No. 3, pp. 393-416.

Grinblatt, M. and Titman, S. (1993), "Performance measurement without benchmarks: an examination of mutual fund returns", Journal of Business, Vol. 66 No. 1, pp. 47-68.

Gu, Q. (2015), Size and Book-To-Market Factors in Returns, All Graduate Plan B and other Reports, p. 673.

Hackethal, A., Haliassos, M. and Jappelli, T. (2012), "Financial advisors: a case of babysitters?”, Journal of Banking and Finance, Vol. 36 No. issue 2, 2012, pp. 509-524.

Howe, T. and Pope, R. (1996), "Equity mutual fund historical performance ratings", Journal of Financial and Strategic Decisions, Vol. 9 No. 1, pp. 33-43.

Jin, L., Eshraghi, A., Taffler, R. and Goyal, A. (2016), "Fund Manager Active Share, overconfidence and investment performance, FMA conference", available at: http://www.fmaconferences.org/ Vegas/Papers/FundManagerActiveShare-15.01.16.pdf.

Kacperczyk, M., Sialm, C. and Zheng, L. (2005), "On the industry concentration of actively managed equity mutual funds”, The Journal of Finance, Vol. 60 No. 4, pp. 1983-2011.

Kanury, S. and Mcleod, R. (2016), "Sustainable competitive advantage and stock performance: the case for wide moat stocks", Applied Economics, Vol. 48 No. 52, pp. 5117-5127.

Karabulut, Y. (2013), "Financial advice: an improvement for worse?", Working Paper, available at: https://ssrn.com/abstract $=1710634$.

Kempf, E., Maconi, A. and Spalt, O. (2017), "Learning by doing: the value of experience and the origins of skill for mutual fund managers", available at: http://papers.ssrn.com/sol3/papers.cfm? abstract_id=2124896.

Lakonishok, J., Shleifer, A. and Vishny, R.W. (1994), “Contrarian investment, extrapolation, and risk”, The Journal of Finance, Vol. 49 No. 5, pp. 1541-1578.

Meinhardt, C. (2014), "Ratings and performance of German mutual funds - a comparison of feri trust, finanztest and FondsNote", available at: https://ssrn.com/abstract $=1943577$ or http://dx.doi.org/ 10.2139/ssrn.1943577.

Mohanram, P. (2005), "Separating winners from losers among low book-to-market stocks using financial statement analysis", Review of Accounting Studies, Vol. 10 Nos 2-3, pp. 33-170.

Morey, M.R. (2005), "The kiss of death: a 5-star morningstar mutual fund rating?", Journal of Investment Management, Vol. 3 No. 2, pp. 41-52.

Morey, M.R. and Gottesman, A.A. (2006), "Morningstar mutual fund ratings redux", Journal of Investment Consulting, Vol. 8 No. 1, pp. 25-37.

Müller, S. and Weber, M. (2014), "Evaluating the rating of stiftung warentest: how good are mutual fund ratings and can they be improved?”, European Financial Management, Vol. 20 No. 2, pp. 207-235.

Niessen, A. and Ruenzi, S. (2007), Sex Matters: Gender Differences in a Professional Setting, Working Paper, University of Cologne.

Novy-Marx, R. (2013), “The other side of value: the gross profitability premium”, Journal of Financial Economics, Vol. 108 No. 1, pp. 1-28.

Otero, L. and Durán, P. (2021), "Is quantitative and qualitative information relevant for choosing mutual funds?", Journal of Business Research, Vol. 123, pp. 476-488.

Otero, L., Durán, P. and Domíngues, R. (2020), "Do investors obtain better results selecting mutual funds through quantitative ratings?”, Spanish Finance and Accounting Review, Vol. 49, pp. 265-291.

O'Shaughnessy, J. (2011), What Works on Wall Street, 4th ed., McGraw-Hill, New York. 
Paramés, F. (2016), Long Term Investing, 2016, Deusto, Bilbao.

Petajisto, A. (2013), “Active share and mutual fund performance”, Financial Analysts Journal, Vol. 69 No. 4, pp. 73-93.

Piotroski, J.D. and So, E.C. (2013), "Identifying expectation errors in value/glamour strategies: a fundamental analysis approach", Review of Financial Studies, Vol. 25 No. 9, pp. 2841-2875.

Pontiff, J. and Schall, L.D. (1998), "Book-to-Market ratios as predictors of market returns", Journal of Financial Economics, Vol. 49 No. 2, pp. 141-160.

Reinganum, M.R. (1981), "Misspecification of capital asset pricing: empirical anomalies based on earnings' yields and market values", Journal of Financial Economics, Vol. 9 No. 1, pp. 19-46.

Roodman, D. (2009), "A note on the theme of too many instruments", Oxford Bulletin of Economics and Statistics, Vol. 71 No. 1, pp. 135-158.

Rosenberg, B., Reid, K. and Lanstein, R. (1985), "Pervasive evidence of market inefficiency”, Journal of Portfolio Management, Vol. 9 No. 3, pp. 18-28.

Shleifer, A. and Vishny, R. (1997), "The limits of arbitrage”, The Journal of Finance, Vol. 52, pp. 35-55.

Sorensen, E.H. and Fabozzi, F.J. (2008), "Growth and value investing-keeping in style", in Fabozzi, F.J. (Ed.), Handbook of Finance, Wiley. doi: 10.1002/9780470404324.hof002030.

Stattman, D. (1980), "Book values and stock returns", The Chicago MBA: A Journal of Selected Papers, Vol. 4, pp. 25-45.

Wermers, R. (2000), "Mutual fund performance: an empirical decomposition into stock-picking talent, style, transactions costs, and expenses", The Journal of Finance, Vol. 55 No. 4, pp. 1655-1695.

\section{Corresponding author}

Luis Otero-González can be contacted at: oterogonzalezluis@gmail.com

For instructions on how to order reprints of this article, please visit our website:

www.emeraldgrouppublishing.com/licensing/reprints.htm

Or contact us for further details: permissions@emeraldinsight.com 